\title{
Beyond Brexit
}

\section{Fiona Godlee editor in chief}

The BMJ

The UK has voted to leave the EU, immediately catapulting the country into constitutional chaos. The $B M J$ had shown its colours by urging readers to vote to remain (doi:10.1136/bmj. i3302) — much to some readers' fury (bmj.com/content $/ 353 / \mathrm{bmj}$. i3302/rapid-responses).

We did this because we believed that health would fare better if we stayed in Europe. Sadly, the immediate effect of the vote on financial markets gives little room for hope that we were wrong. Funding for health depends on political will and economic stability - both of which will now be in short supply.

The blame game may go on for some time. There is anger at the prime minister for calling the referendum in the first place and for failing to have a plan in case he lost; and anger at the collective failure of successive governments to notice, let alone try to tackle, the UK's deepening social divide.

But blame won't get us very far: we have to work within the new reality. In an attempt to look forward this week, we report voices from across UK healthcare (doi:10.1136/bmj.i3591). There is anger and sadness about the results, and concern for the future. Many predict worsening staff shortages in the NHS (doi:10.1136/bmj.i3604) and the collapse of research budgets (doi:10.1136/bmj.i3600).

But some find things to celebrate in a new relationship with Europe. The UK can now dispense with the worst excesses of the European Working Time Directive- - which drove the UK's doctors into shift working and helped to destroy the traditional medical firm. Released from the directive's strictures, we can develop new ways of working and training that restore some of what was lost.

Nurse training can also be released from EU requirements that Nicky Cullum says are onerous and unnecessary. Thomas Nixon looks forward to a level playing field for doctors coming to the UK from outside the EU, and Mike Dixon to less red tape and an end to European competition rules (doi:10.1136/bmj.i3591). These may be chinks of light in the darkness. We will search for others in the weeks ahead. But as individuals and as a profession there is much for us to do. Above all, if we want to promote health, we need to make the case for a much fairer and more equal society than has been revealed in this referendum result. 